\title{
Epidemiology and Molecular Aspect of Pediculosis Among Primary School Children in Sulaimani Province Kurdistan-Iraq
}

\author{
Abdullah A. Haama \\ Research center \\ Technical College of Health \\ Sulaimani Polytechnic University \\ Sulaimani, Iraq \\ abdullah.hama@spu.edu.iq
}

\author{
Aweza M. Mohammed \\ Sulaimani Diarectorate of Health \\ Sulaimani, Iraq \\ Awezaamin98@gmail.com \\ Sina K. Esmail \\ Sulaimani Diarectorate of Health \\ Sulaimani, Iraq \\ sina.khali198@gmail.com
}

Sumaya K. Esmail

Sulaimani Diarectorate of Health

Sulaimani, Iraq

sumaya.zhyar99@gmail.com

\author{
Harun S. Sdiq \\ Research center \\ Sulaimani Polytechnic University \\ Sulaimani, Iraq \\ harun.m.1.2016@gmail.com
}

Aziz I. Ahmed

Sulaimani Diarectorate of Health

Sulaimani, Iraq

azizedris12@hotmail.com

Hevan A. Hama

Sulaimani Diarectorate of Health

Sulaimani, Iraq

hevan.abdul@gmail.com

\begin{tabular}{l} 
Article Info \\
\hline Volume 5-Special Issue: $4^{\text {th }}$ \\
International Conference on the \\
Health and Medical Science : \\
Medical Researches Improve Life \\
Quality (ICHMS 2020) \\
DOI: \\
10.24017/science.2020.ICHMS2020.1 \\
Article history: \\
Received: 04 October 2020 \\
Accepted: 10 October 2020 \\
\hline
\end{tabular}

Keywords:

Head lice, Pediculosis, Parasite, Primarischool children, itching, PCR.

\begin{abstract}
Pediculosis is the term for head lice (Pediculus humanus capitis) and the other hairy parts infestation with any stages of lice. The lice are a human blood sucking ecto-parasite which can cause severe itching. Direct contact, Sharing of clothing and combs can be a way for lice transmission from infected person to another.This study had been done to determine the pediculosis infection rate and risk factors asociassion with head lice among primary schools children in Sulaimani Province, all cases were evaluated by physical examination (visual inspection) and detail structured questionnaire which was including education levels, family size, hair washing frequency, type and length of hair, mother occupation and education, father occupation, and education was used, the polymerase chain reaction (PCR) used for confirming the head lice clade. A total of 4087 students was inspected from 13 primary schools in Sulaimani
\end{abstract}


city, with the overall prevalence of $8.3 \%$, The participants were 2046 males and 2041 females with prevalence $2.20 \%$ and $6.1 \%$ respectively. The age of respondents was between 5-13 years. The prevalence was higher in large family members in comparing to those with small family members. The amplicons product from Polymarase chain Reaction was visualized on $1.5 \%$ agarose gel, and expected DNA band size of head lice's was approximately 486 bp which confirms that these lice's belong to the head lice group clade $A$. In conclusion the school aged children in Sulaimani province were suffering from peiculosis with high prevalence rate and it has a direct impact on children cognitive and school activity performance.

Copyright C 2020 Kurdistan Journal of Applied Research.

All rights reserved.

\section{INTRODUCTION}

The insects are the largest class of Animalia kingdom, about $80 \%$ of the known animal species in the world belongs to insects, and this class includes the medical importance arthropods as parasite and vectors [1]. Lice are an obligate ectoparasite that have various species including: Pediculus humanus capitis, Pediculus humanus corporis, and Phthirus pubis. The adult louse is between 2.5 and $3.5 \mathrm{~mm}$ in length, grayish in color and inhabits the scalp attached to the base of hair [2], they have a sesame seed shape, and are flattened dorsoventrally [3]. Lice belongs to the order: Phthiraptera, which are human ecto-parasites, their life cycle consists of three stages, egg, nymph, and adult. The life span of adult Pediculus humanus capitis is up to 30 days on a human head, it lay up to 10 eggs per day, the adult louse takes a blood meal several times daily and sometimes it can survive for 36 hours without a blood meal [3]. Head lice prefer the scalp surface, which is good source of food, and physically provide good environment. The lice feed on the human blood several times a day [2]. The head lice infestation is a common health concern among children in which have a negative impact on children school activity performance and cognition. Transmission of the lice will be directly from infected person to others or indirectly through sharing the clothes, hairbrushes, combs, headgear, scarves, coats and bedding. The common Symptoms of pediculosis are pruritus, excoriation and redness [4]. Generally, anemia is the most common symptom of ectoparasite and some intestinal parasite infection [5-6]. Also pediculosis may cause myiasis, plica Polonica, and allergic reactions [5]. The head lice may be found rarely on the eyebrows. While head lice prefer to remain on the head and behind the ears. The overcrowded and personal hygiene have significant effect on pediculosis among children, symptoms of infestation include pruritus and cervical lymphadenopathy [7]. Excoriation and secondary bacterial infection from scratching [8]. Although there are no studies indicates that head lice become a vector for any pathogenic microorganisms [7].

Light infestations may produce slight itching of the scalp by louse saliva. Severe infestations, however, may cause restlessness, aches, pruritus, and fever [9]. The most common presenting symptom of infestation is scalp itching, but sometimes lice can be present without itching, from one week to three months after infestation itching can attack while lack of itching does not mean that there is no lice infestation. If impetigo present on the skin that caused by bacteria, scalp sore may produce and lead to increase children's body temperature and feel unwell [10]. The spread and infestation of pediculosis was relatively high among children in the United States, and incidence rate was about 6 to 12 million infestations each year. Some study shows that the girls get head lice infestation more than boys [11]. A population-based 
questionnaire survey indicates the prevalence rate of pediculosis in UK is very low in comparison with the other countries [12]. There was a intimate relation between lice infestation and several risk factors, including, personal hygiene, lifestyle, outdoor activity, hair washing. Transportation mode and head lice infestation have no significant impact with the presence of a house servant [13]. There is no adequate data about pedculosis in Iraq and Kurdistan, The epidemiological study on the pediculocis in Erbil, Kurdistan- Iraq shows the high infestation rate among students (14.52\%) [15]. Recent studies carried out in the Sulaimani province among refugees the low prevalence rates was recorded $(1.12 \%)$, and indicates the infestation was higher among female than the male [1].

\section{METHODS AND MATERIALS}

\section{Epidemiology Study}

This study was carried out among 13 primary schools in Sulaimani, Kurdistan/Iraq located in the longitude (44.50- 46.16) East and latitude (35.04 - 36.30) North. The sampling and data collected with collaborating of Sulaimani directorate of education, 13 primary schools were selected randomly and visited regularly 3 days a week from October 2019 to April 2020. The total participants was 4087 including 2041 female and 2046 male. During a direct interview each participates was inspected for infestation with head lice directly by visual examination, The detection of adult or any developing stages of Head lice was considered infested. After the Head inspection, and according to a questionnaire the: age, gender, school activity, family member, the hair washing per week, length of hair, hair type, sharing a common comb, sharing common cloth or bed and duration of infestation were asked, finally the lice were collected and preserved in ethanol separately for molecular study. The epidemiological data were statistically analyzed by using Graph pad prism and SPSS (version 21).

\section{Molecular Studies}

The DNA was extracted from tissue of each louse $(n=50)$ using Mini Kit of DNA extraction kit from Tissue Protocol and the company instruction was followed to obtain a good quality genomic DNA from the lice tissue, the obtained DNA was preserved in TE buffer $(10 \mathrm{mM}$ Tris $\mathrm{HCl}, 1 \mathrm{mM}$ EDTA).

DNA samples were subjected to standard PCR, using the specific primer set for head lice (Cytb) which was used previously [16]. The PCR profile: one cycle at $95{ }^{\circ} \mathrm{C}$ for $7 \mathrm{~min}$ followed by 40 cycles $\left(1 \mathrm{~min}\right.$ at $94{ }^{\circ} \mathrm{C}, 30 \mathrm{~s}$ at $56^{\circ} \mathrm{C}$ and $40 \mathrm{~s}$ at $72{ }^{\circ} \mathrm{C}$ ), and a final step for $6 \mathrm{~min}$ at $72^{\circ} \mathrm{C}$. The success of amplification was detected by gel-electrophoresis using 1.5 agarose.

\section{RESULTS}

\section{Epidemeology of Pediculosus}

Table 1: Shows the school name, number of inspecting students, number and percentage of positive and negative participants. The result shows that the Qaratoxan primary school had the highest prevalence and percentage of head lice among students, which was $14 \%$, while the lowest infestation of head lice were recorded in Ibrahim Amin Baldar primary school (1.1\%). 
Table 1: Distribution of respondents by school name, number of inspected students, number and percentage of positive and negative participants.

\begin{tabular}{|c|c|c|c|c|c|}
\hline \multirow{2}{*}{ Name of school } & \multirow{2}{*}{$\begin{array}{c}\text { Examined } \\
\text { students }\end{array}$} & \multicolumn{2}{|c|}{ Positive } & \multicolumn{2}{|r|}{ Negative } \\
\hline & & Number & $\begin{array}{c}\text { Percentage } \\
(\%)\end{array}$ & $\begin{array}{c}\text { Numb } \\
\text { er }\end{array}$ & Percentage (\%) \\
\hline Qamishlo & 192 & 13 & 6.7 & 179 & 93.3 \\
\hline Kandasura & 120 & 14 & 11.6 & 106 & 88.4 \\
\hline Kanigoma & 433 & 52 & 12 & 381 & 88 \\
\hline Peshkawtn & 252 & 16 & 6.3 & 236 & 93.6 \\
\hline Hawarabarza & 270 & 13 & 4.8 & 257 & 95.2 \\
\hline Kamyaran & 398 & 31 & 7.8 & 367 & 92.2 \\
\hline Zakia Samy Agha & 382 & 25 & 6.5 & 357 & 93.5 \\
\hline Wluba & 355 & 47 & 13.2 & 308 & 86.8 \\
\hline Qaratokhan & 400 & 56 & 14 & 344 & 86 \\
\hline Asuda & 343 & 8 & 2.3 & 335 & 97.6 \\
\hline $\begin{array}{l}\text { Ibrahim Amin } \\
\text { Baldar }\end{array}$ & 282 & 3 & 1.1 & 279 & 98.9 \\
\hline Qandil & 325 & 30 & 9.2 & 295 & 90.8 \\
\hline Hawraman & 335 & 32 & 9.5 & 303 & 90.4 \\
\hline Total & 4087 & 340 & 8.3 & 3747 & 91.7 \\
\hline
\end{tabular}

Table 2 Shows the distribution of numbers and percentages of infested, non infested and the prevalence of Pediculosis among primary school children with associated risk factors of head lice infestation. The risk factors include educational level, family size, frequency of hair washing, length of hair, hair type, common comb, common cloth or bed, scalp disease, father education, father's occupation, mother education and mother occupation

The result shows the pediculosis was higher among families which have family members more than 7 members than those who have smaller family size out of 555 cases $74(13.3 \%)$ were more than seven members were out of 240 cases $11(4.58 \%)$ cases had afamily size between 1- 3 members. Pediculosis prevalence depending on frequency of hair washing shows there is no significant ( $p>0.05$ ) effect of hair washing one time to three times a week on head pediculosis. The result of head infestation was higher significantly among children with long hair in comparison to others with short hair out of 721 cases $91(12.62 \%)$ were having long hair while out of 2060 cases 108 (5.24\%) cases had a short hair.

Table 2: The Prevalence rate and risk factors of pediculosis among primary school children in Sualaimani Province.

\begin{tabular}{|c|c|c|c|c|c|c|c|c|c|}
\hline \multirow{2}{*}{\multicolumn{2}{|c|}{ Characteristic (Factors) }} & \multicolumn{2}{|c|}{ Inspected } & \multicolumn{2}{|c|}{ Non-infested } & \multicolumn{2}{|c|}{ Infested } & \multirow{2}{*}{$\begin{array}{l}\text { Prevalenc } \\
\text { e of } \\
\text { pediculosi } \\
\text { s }\end{array}$} & \multirow{2}{*}{$\begin{array}{l}\text { P- } \\
\text { value }\end{array}$} \\
\hline & & No. & $\%$ & No. & $\%$ & $\begin{array}{l}\text { No } \\
\cdot \\
\end{array}$ & $\%$ & & \\
\hline \multirow{3}{*}{$\begin{array}{l}\text { Family } \\
\text { size }\end{array}$} & 1-3 Persons & 240 & $\begin{array}{l}5.8 \\
7\end{array}$ & 229 & $\begin{array}{l}5.6 \\
0\end{array}$ & 11 & $\begin{array}{l}0 . \\
26\end{array}$ & $4.58 \%$ & \multirow{3}{*}{$\begin{array}{c}0.000 \\
1\end{array}$} \\
\hline & 3-4 Persons & 1007 & $\begin{array}{l}24 . \\
6\end{array}$ & 941 & $\begin{array}{l}23 . \\
02\end{array}$ & 66 & $\begin{array}{l}1 . \\
61\end{array}$ & $6.55 \%$ & \\
\hline & 5-6person & 2285 & $\begin{array}{l}55 . \\
9\end{array}$ & 2082 & $\begin{array}{l}50 . \\
9\end{array}$ & $\begin{array}{l}20 \\
3\end{array}$ & $\begin{array}{l}4 . \\
96\end{array}$ & $8.88 \%$ & \\
\hline
\end{tabular}

Kurdistan Journal of Applied Research $\mid 4^{\text {th }}$ International Conference on the Health and Medical Science: Medical Researches Improve Life Quality (ICHMS 2020) $\mid 4$ 


\begin{tabular}{|c|c|c|c|c|c|c|c|c|c|}
\hline & More than 7 & 555 & $\begin{array}{l}13 . \\
57\end{array}$ & 481 & $\begin{array}{l}11 . \\
7\end{array}$ & 74 & $\begin{array}{l}1 . \\
81\end{array}$ & $13.3 \%$ & \\
\hline \multirow{3}{*}{$\begin{array}{c}\text { Freque } \\
\text { ncy of } \\
\text { hair } \\
\text { washing }\end{array}$} & Once a week & 722 & $\begin{array}{l}17 . \\
6\end{array}$ & 676 & $\begin{array}{l}16 . \\
5\end{array}$ & 46 & $\begin{array}{l}1 . \\
12\end{array}$ & $6.37 \%$ & \multirow{3}{*}{0.02} \\
\hline & Twice a week & 1575 & $\begin{array}{l}38 . \\
5\end{array}$ & 1444 & $\begin{array}{l}35 . \\
3\end{array}$ & $\begin{array}{l}13 \\
1\end{array}$ & $\begin{array}{l}3 . \\
20\end{array}$ & $8.32 \%$ & \\
\hline & $\begin{array}{c}\text { Three or more a } \\
\text { week }\end{array}$ & 1790 & $\begin{array}{l}43 . \\
7\end{array}$ & 1613 & $\begin{array}{l}39 . \\
4\end{array}$ & $\begin{array}{l}17 \\
7\end{array}$ & $\begin{array}{l}4 . \\
33\end{array}$ & $9.89 \%$ & \\
\hline \multirow{3}{*}{$\begin{array}{l}\text { Length } \\
\text { of hair }\end{array}$} & Short & 2060 & $\begin{array}{l}50 . \\
4\end{array}$ & 1952 & $\begin{array}{l}47 . \\
7\end{array}$ & $\begin{array}{l}10 \\
8\end{array}$ & $\begin{array}{l}2 . \\
64\end{array}$ & $5.24 \%$ & \multirow{3}{*}{0.001} \\
\hline & Medium & 1305 & $\begin{array}{l}31 . \\
9\end{array}$ & 1150 & $\begin{array}{l}28 . \\
1\end{array}$ & $\begin{array}{l}15 \\
5\end{array}$ & $\begin{array}{l}3 . \\
79\end{array}$ & $11.88 \%$ & \\
\hline & Long & 721 & $\begin{array}{l}17 . \\
6\end{array}$ & 631 & $\begin{array}{l}15 . \\
4\end{array}$ & 91 & $\begin{array}{l}2 . \\
22\end{array}$ & $12.62 \%$ & \\
\hline \multirow{3}{*}{$\begin{array}{l}\text { Hair } \\
\text { type }\end{array}$} & Straight hair & 3098 & $\begin{array}{l}75 . \\
8\end{array}$ & 2864 & $\begin{array}{l}70 . \\
0\end{array}$ & $\begin{array}{l}23 \\
4\end{array}$ & $\begin{array}{l}5 . \\
72\end{array}$ & $7.55 \%$ & \multirow{3}{*}{$\begin{array}{c}0.000 \\
1\end{array}$} \\
\hline & Wavy hair & 394 & $\begin{array}{l}9.6 \\
4\end{array}$ & 351 & $\begin{array}{l}8.5 \\
8\end{array}$ & 43 & $\begin{array}{l}1 . \\
05\end{array}$ & $10.91 \%$ & \\
\hline & Curly (spring) & 595 & $\begin{array}{l}14 . \\
5\end{array}$ & 518 & $\begin{array}{l}12 . \\
6\end{array}$ & 77 & $\begin{array}{l}1 . \\
88\end{array}$ & $12.94 \%$ & \\
\hline \multirow{2}{*}{$\begin{array}{l}\text { commo } \\
\text { n comb }\end{array}$} & Yes & 875 & $\begin{array}{l}21 . \\
4\end{array}$ & 795 & $\begin{array}{l}19 . \\
4\end{array}$ & 80 & $\begin{array}{l}1 . \\
95\end{array}$ & $9.14 \%$ & \multirow{2}{*}{0.6} \\
\hline & No & 3212 & $\begin{array}{l}78 . \\
5\end{array}$ & 2938 & $\begin{array}{l}71 . \\
8\end{array}$ & $\begin{array}{l}27 \\
4\end{array}$ & $\begin{array}{l}6 . \\
7\end{array}$ & $8.53 \%$ & \\
\hline \multirow{2}{*}{$\begin{array}{l}\text { commo } \\
\text { n cloth } \\
\text { or bed }\end{array}$} & Yes & 427 & $\begin{array}{l}10 . \\
4\end{array}$ & 384 & $\begin{array}{l}9.3 \\
9\end{array}$ & 43 & $\begin{array}{l}1 . \\
05\end{array}$ & $10.07 \%$ & \multirow{2}{*}{0.03} \\
\hline & No & 3660 & $\begin{array}{l}89 . \\
5\end{array}$ & 3349 & $\begin{array}{l}81 . \\
9 \\
\end{array}$ & $\begin{array}{l}31 \\
1\end{array}$ & $\begin{array}{l}7 . \\
60 \\
\end{array}$ & $8.50 \%$ & \\
\hline \multirow{2}{*}{$\begin{array}{c}\text { Scalp } \\
\text { disease }\end{array}$} & Yes & 92 & $\begin{array}{l}2.2 \\
5\end{array}$ & 78 & $\begin{array}{l}1.9 \\
0\end{array}$ & 14 & $\begin{array}{l}0 . \\
34\end{array}$ & $15.22 \%$ & \multirow{2}{*}{0.038} \\
\hline & No & 3995 & $\begin{array}{l}97 . \\
7\end{array}$ & 3655 & $\begin{array}{l}89 . \\
4\end{array}$ & $\begin{array}{l}34 \\
0\end{array}$ & $\begin{array}{l}8 . \\
31\end{array}$ & $8.51 \%$ & \\
\hline \multirow{2}{*}{$\begin{array}{l}\text { Father } \\
\text { educati } \\
\text { on }\end{array}$} & Yes & 3515 & $\begin{array}{l}86 . \\
0\end{array}$ & 3224 & $\begin{array}{l}78 . \\
8\end{array}$ & $\begin{array}{l}29 \\
1\end{array}$ & $\begin{array}{l}7 . \\
12\end{array}$ & $8.28 \%$ & \multirow{2}{*}{0.06} \\
\hline & No & 527 & $\begin{array}{l}12 . \\
89 \\
\end{array}$ & 470 & $\begin{array}{l}11 . \\
4\end{array}$ & 57 & $\begin{array}{l}1 . \\
39 \\
\end{array}$ & $10.82 \%$ & \\
\hline \multirow{4}{*}{$\begin{array}{c}\text { Father } \\
\text { ocupati } \\
\text { on }\end{array}$} & Worker & 2598 & $\begin{array}{l}63 . \\
5\end{array}$ & 2364 & $\begin{array}{l}57 . \\
8\end{array}$ & $\begin{array}{l}23 \\
4\end{array}$ & $\begin{array}{l}5 . \\
72 \\
\end{array}$ & $9.0 \%$ & \multirow{4}{*}{0.13} \\
\hline & Employe & 979 & $\begin{array}{l}23 . \\
5\end{array}$ & 902 & $\begin{array}{l}22 . \\
0\end{array}$ & 77 & $\begin{array}{l}1 . \\
88\end{array}$ & $7.87 \%$ & \\
\hline & Others & 439 & $\begin{array}{l}10 . \\
7\end{array}$ & 405 & $\begin{array}{l}9.9 \\
0\end{array}$ & 34 & $\begin{array}{l}0 . \\
83\end{array}$ & $7.74 \%$ & \\
\hline & Not & 71 & 1.7 & 62 & $\begin{array}{l}1.5 \\
1\end{array}$ & 9 & $\begin{array}{l}0 . \\
22\end{array}$ & $12.68 \%$ & \\
\hline \multirow{2}{*}{$\begin{array}{c}\text { Mother } \\
\text { Educati } \\
\text { on }\end{array}$} & Yes & 3327 & $\begin{array}{l}81 . \\
4\end{array}$ & 3063 & $\begin{array}{l}74 . \\
9\end{array}$ & $\begin{array}{l}26 \\
4\end{array}$ & $\begin{array}{l}6 . \\
45\end{array}$ & $7.94 \%$ & \multirow{2}{*}{$\begin{array}{c}0.001 \\
3\end{array}$} \\
\hline & No & 746 & $\begin{array}{l}18 . \\
6\end{array}$ & 659 & $\begin{array}{l}16 . \\
1\end{array}$ & 87 & $\begin{array}{l}2 . \\
12\end{array}$ & $11.66 \%$ & \\
\hline \multirow{4}{*}{$\begin{array}{c}\text { Mother } \\
\text { Occupa } \\
\text { tion }\end{array}$} & House wife & 3071 & $\begin{array}{l}75 . \\
1\end{array}$ & 2791 & $\begin{array}{l}68 . \\
2\end{array}$ & $\begin{array}{l}28 \\
0\end{array}$ & $\begin{array}{l}6 . \\
85\end{array}$ & $9.12 \%$ & \multirow{4}{*}{0.015} \\
\hline & Employe & 847 & $\begin{array}{l}20 . \\
7\end{array}$ & 785 & $\begin{array}{l}19 . \\
2\end{array}$ & 62 & $\begin{array}{l}1 . \\
51\end{array}$ & $7.32 \%$ & \\
\hline & Others & 153 & $\begin{array}{l}3.7 \\
4\end{array}$ & 145 & $\begin{array}{l}3.5 \\
4\end{array}$ & 8 & $\begin{array}{l}0 . \\
19 \\
\end{array}$ & $5.23 \%$ & \\
\hline & Not & 16 & $\begin{array}{l}0.3 \\
9\end{array}$ & 12 & $\begin{array}{l}0.2 \\
9\end{array}$ & 4 & $\begin{array}{l}0 . \\
09\end{array}$ & $25 \%$ & \\
\hline
\end{tabular}

Kurdistan Journal of Applied Research $\mid 4^{\text {th }}$ International Conference on the Health and Medical Science: Medical Researches Improve Life Quality (ICHMS 2020) $\mid 5$ 
Table 3 shows the prevalence of pediculosis among different age groups. The total prevalence of Pediculosis was $8.3 \%$. The age of participants is classified into three different age groups which are (5-7 years), (8-10 years) and (11-13 years). The highest prevalence rate of head lice infestation was recorded among age group (8-10 years) with 152 (43.30\%), and the students of age 11 to 13 years shows about $139(39.60 \%)$ cases out of 1368 inspected students. The lowest prevalence is reported among 5 to 7 years old students, which was $60(17.09 \%)$ out 831 inspected participants.

Table 3: The age factor and Prevalence of pediculosis

\begin{tabular}{|c|c|c|c|c|c|}
\hline \multirow{2}{*}{ Age (years) } & \multicolumn{2}{|c|}{$\begin{array}{c}\text { Examined } \\
\text { Samples }\end{array}$} & \multicolumn{2}{|c|}{ Positive Sample } & \multirow[t]{2}{*}{ P-Value } \\
\hline & No. & $(\%)$ & No. & $(\%)$ & \\
\hline $5-7$ & 881 & $21.55 \%$ & 59 & $17.35 \%$ & \multirow{4}{*}{0.07} \\
\hline $8-10$ & 1831 & $44.80 \%$ & 151 & $44.41 \%$ & \\
\hline $11-13$ & 1378 & $33.65 \%$ & 130 & $38.23 \%$ & \\
\hline Total & 4087 & $100 \%$ & 340 & $8.3 \%$ & \\
\hline
\end{tabular}

\section{PCR and gel electrophoresis of head lice}

Gel electrophoresis results of 11 samples were run. The test used to confirm that to which group of lice the samples are belong, fortunately as we expected samples were belong to head lice group with the genome size of $486 \mathrm{kbp}$. Pair of primers called head Cytb with the sequence (Forward primer: GAG CGA CTG TAA TTA CTAATC Reverse primer: CAACAA AAT TAT CCG GGT CC) was used in PCR technique. The PCR was to determine the genetic aspect of the lice and to determine the clade of the isolated lice[30].

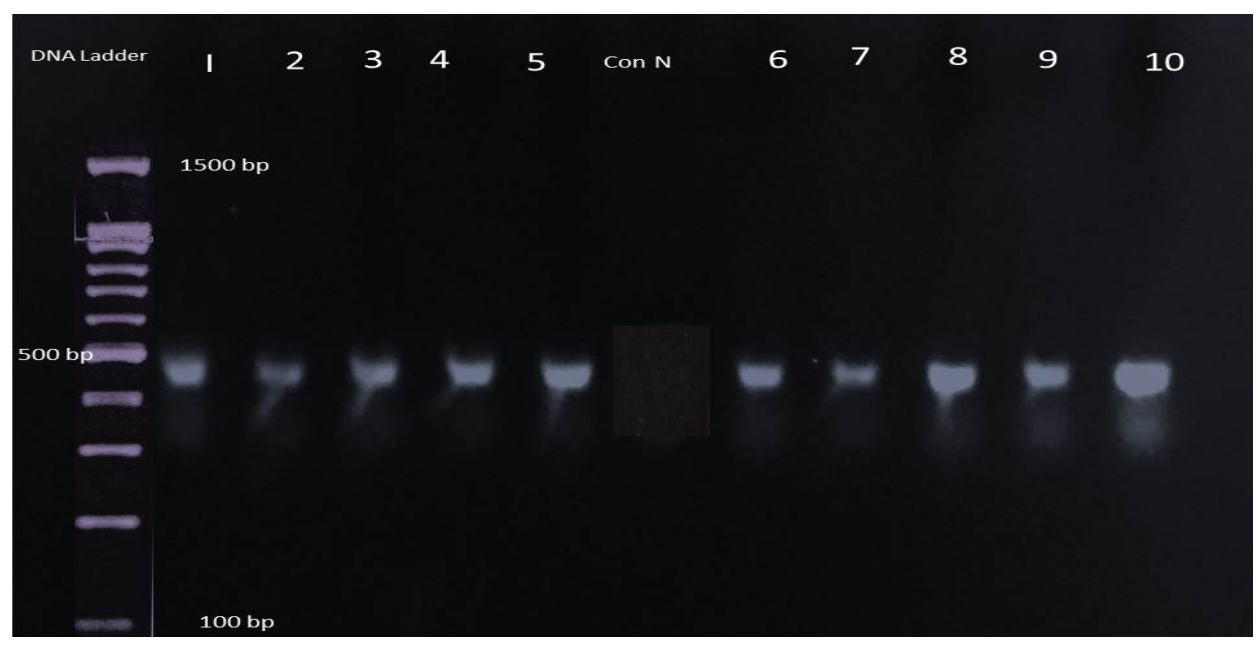

Figure 1: Gel electrophoresis represent the results of the PCR products on 1.5\% agarose gel. DNA ladder, 1-10 sample, Con $\mathrm{N}=$ Negative control

\section{DISCUSSION}

\section{Prevalence of head Pediculosis among primary aged school children}

The prevalence rate of Pediculosis in primary aged school children in this study was $8.3 \%$, which is in agreement with the research carried out in Mercin Turkey which was 8.6\% [17]. The our finding is higher as compared to that reported in the eastern region of the European Union $(2.01 \%)$ among school children [18] it may be due to the culture and socioeconomic factors, personal hygiene and the health system of the each country. The prevalence of 
Pediculosis in this study is lower than that of a similar study among primary aged school children in Erbil city Iraq (14.52\%) [14]. The high prevalence rate of pediculosis was recorded in Bangkok, Thailand (23.32\%) [119] many factors have an impact on the pediculosis prevalence rate; the method of diagnosuis, prevention and eradication methods, pediculocide and knowledge regarding lice as a health problem. Also moisture and suitable environment provide growth and prevalence of head Pediculosis as poor hygiene and socioeconomic, season and lack of good medical treatment [1].

As shown in table 3 head lice infestation was most prevalent among students that are between 8-10 years of age with no significant difference $(\mathrm{P}>0.05)$ in comparing to that reported in Erbil, Iraq Kurdistan region where the prevalence Pediculosis was significantly higher among 6-7 years aged students [20]. In another study that reported in the Mersin-turkey region exhibited high prevalence in ages of 10-12 years. The reason for this high rate may be due to poor hygiene and close contact of students together when they play and do their schoolwork's during 8-10 years of age [17].

The head Pediculosis was significantly higher among those children who have a curly hair $(\mathrm{P}=0.0001)$ in comparison to Mexico indicated the prevalence of head lice was higher among who have straight hair [21] this result may be affected by sample size and quality of head shampoo.

The head lice infestation was significantly $(\mathrm{P}=0.001)$ higher among student who have a long hair $(12.62 \%)$ in compare to others with short hair (5.24\%). In contrast, of our result the study in New York suggests that hair length has no effect on the head lice distribution [22]. While another study in Baghdad, which is supporting our finding indicates the long hair girls were much more infested with Pediculus capitis $(22.2 \%)$ than those with medium or short hair which is similar with collected data in this study [23]. As well as the high prevalence rate of head lice among children with long hair were recorded in Jordan it is more difficult to comb and keep clean the long hair in comparison with short hair [24].

The pediculosis was found to be significantly associated with a low frequency of bathing in a study reported in Iran [25]. While in present study the significant effect of hair washing was observed $(\mathrm{p}<0.05)$. high Pediculosis was found among students who was washing their hair three time or more per week while the pediculosis among students who washing their hair once or twice a week was lower than, this is may be due to removing the nit and the shampoo will be has direct effect on the head lice.

The result of the present study shows that the infestation with Pediculosis among females had significantly higher than males this finding is similar to the study carried out in Hamadan, Iran who reported high prevalence rate of head lice among females $13.5 \%$ [26]. Also, most studies reported the prevalence rate of head lice infestation was higher among female in comparsion with the male [24] this is may be due to the style life of female they have long hair and also they will use the fomite sharing between them.

Also family size has negative impact on the head lice spread, the high prevalence rate was found among most children who have families with 5-6 persons, which is significantly differ from those who have small family $\operatorname{size}(\mathrm{P}=0.0001)$, in similar study in central Iran it was reported the head lice infestation was significantly increased among large size family [27], while in Kashan Iran shows a positive relationship between the family size and lice infestation [28], in Jordan most prevalence with large family members $>10$ [24]. It is well known that head lice is transmitted directly from person to person and crowded families are mostly at risk for pediculosis.

The infestation ratio of pediculosis according to father education was $8.28 \%$ for educated father stufents and non-educated farther students was $10.82 \%$ and show that students with educated father are less infested than those who have non educated father, otherwise another study done in Garmsar City, Semnan Province, Iran shows that student with educated father are more infested than those have non educated father [29]. Also in a recent study carridout in northwest Ethiopia [30] have same result, while the our result have agreed with a study done in Turkey which indicated the student have an educated father are less infested compare to others that have non educated father this is may be due to the awearness of the fathers about 
the pediculosis and also the educated fathr and mother expected to hav a good personal hygene and health care knowledges.

The prevalence of pediculosis based on mother education the result was higher significantly among non-educated mother students in comparing to educate mother students, this might be due to giving adequate information about personal hygiene and sanitary conditions by their mothers. Same findings reported in northwest Ethiopia [28].

\section{CONCLUSION}

This study concluded that the prevalence Pediculosis among primary school children is high $(8.3 \%)$ in Sulaimani Province, the age, hair type and education are the common risk factors which have a significant effect on the head lice distribution, Pediculosis was higher among females than those of males and Pediculosis has negative impact on the school activity performance.

\section{REFERENCE}

[1] F.M. Ali, A.A. Hama, "Prevalence of Head Pediculosis Among Refugees In Sulaimani Governorate/KurdistanIraq," Iraqi Journal of Science, 59(2), pp.1012-8, 2018.

[2] J. Harman, P. Mason, Handbook of pharmacy healthcare diseases and patient advice, Pharmaceutical Press, London. 2002.

[3] Z. Yong, P.É. Fournier, E. Rydkina, D. Raoult, "The geographical segregation of human lice preceded that of Pediculus humanus capitis and Pediculus humanus," Comptes Rendus Biologies, 326(6), pp.565-74, 2003.

[4] B. Madke, U. Khopkar, "Pediculosis capitis: An update," Indian Journal of Dermatology Venereology and Leprology, 78(4), pp.429-438, 2012.

[5] G. Chandralekha, "A Study to Assess the Effectiveness of Neem Leaves Powder (Azadrichta Indica) on Pediculosis Among School Children at A selected community in Chennai," International Journal for Advance Research and Development, 2(7), pp.29-32, 2017.

[6] A. A. Hama and Z. I. F. Rahemo, "Intestinal parasitosis in relation to haemoglobin concentration among primary schoolchildren in erbil province kurdistan-iraq,” International Science Journal, 1(1),pp. 96-99, 2014.

[7] C. Cummings, J.C. Finlay, N..E. MacDonald, "Head lice infestations: A clinical update," Paediatrics \& child health, 23(1), pp.18-24, 2018.

[8] A. Judith, " Professional guide to diseases", Wolters Kluwer Health- Lippincott Williams \& Wilkins, Philadelphia, 2012.

[9] C. Burhgardt, "Lippincott's Guide to Infectious Diseases", Wolters Kluwer Health- Lippincott", Williams \& Wilkins, Philadelphia, 2011.

[10] G. B. White, "Insects and hygiene. The biology and control of insect pests of medical and domestic importance. James R. Busvine, 1980 (3rd edition). London \& New York: Chapman and Hall,” Transactions of The Royal Society of Tropical Medicine and Hygiene, (75) 3, pp. 388-388, Jan. 1981.

[11] A.M. Downs, K.A. Stafford, G.C. Coles, "Head lice: prevalence in schoolchildren and insecticide resistance," Parasitology Today, 15(1), pp.1-4, 1999

[12] J. Harris, J.G. Crawshaw, S. Millership, "Incidence and prevalence of head lice in a district health authority area," Communicable disease and public health, 6 (3), pp.246-9, 2003.

[13] C. Cummings, J.C. Finlay, N.E. MacDonald, "Head lice infestations: A clinical update," Paediatrics \& child health, 23(1), pp.18-24, 201.

[14] K.N. Khidhir, C.K. Mahmood, W.K. Ali, "Prevalence of infestation with head lice Pediculus humanus capitis (De Geer) in primary schoolchildren in the centre of Erbil city, Kurdistan region, Iraq," Pakistan Entomologist, 39(2), pp.1-4, 2017.

[15] K.S. Al-Marjan, Q.M. Koyee, S.M. Abdullah, "In vitro study on the morphological development of eggs (nits) and other stages of head lice Pediculus humanus capitis De Geer," Zanco Journal of Pure and Applied Sciences, 27(3), pp.35-40, 2015.

[16]B. Koyo, C.S. Amanzougaghene, N. Davoust, B. et al. "Genetic diversity of human head lice and molecular detection of associated bacterial pathogens in Democratic Republic of Congo". Parasites Vectors 12, 290 (2019).

[17] A. Kokturk, K. Baz, R. Bugdayci, T. Sasmaz, U. Tursen, T.I. Kaya, G. Ikizoglu, "The prevalence of pediculosis capitis in schoolchildren in Mersin, Turkey," International journal of dermatology, 42(9), pp.694-8, 2003.

[18] K. Bartosik, A. Buczek, Z. Zajac, J. Kulisz, "Head pediculosis in schoolchildren in the eastern region of the European Union," Annals of Agricultural and Environmental Medicine, 22(4), pp.599-603, 2015.

[19] W. Rassami, M. Soonwera, "Epidemiology of pediculosis capitis among schoolchildren in the eastern area of Bangkok, Thailand," Asian Pacific Journal of Tropical Biomedicine, 2(11), pp.901-4, 2012.

[20] 20 B.S. Abdulla, "Morphological study and Prevalence of head lice (Pediculus humanus capitis)(Anoplura: Pediculidae) infestation among some primary school students in Erbil City, Kurdistan region," ZANCO Journal of Pure and Applied Sciences, 27(5), pp.29-36, 2015. 
[21] 21 P. Manrique-Saide, N. Pavía-Ruz, J.C. Rodríguez-Buenfil, R. Herrera Herrera, P. Gómez-Ruiz, D. Pilger, "Prevalence of pediculosis capitis in children from a rural school in Yucatan, Mexico," Revista do Instituto de Medicina Tropical de São Paulo, 53(6), pp.325-7, 2011.

[22] G.F. Slonka, M.L. Fleissner, J. Berlin, J. Puleo, E.K. Harrod, M.G. Schultz, "An epidemic of Pediculosis capitis," The Journal of parasitology, 63(2), pp.377-83, 1977.

[23] 23 S.A. Mahmood, "Head pediculosis among in Baghdad area elementary schoolchildren," Iraqi Journal of Science, 51(1), pp.49-55, 2010.

[24]24 M. Al Bashtawy, F. Hasna, "Pediculosis capitis among primary-school children in Mafraq Governorate, Jordan,” Eastern MediterraneanHealth Journal, 18(1), pp.43-48, 2012.

[25] M. Moosazadeh, M. Afshari, H. Keianian, A. Nezammahalleh, A.A. Enayati. "Prevalence of head lice infestation and its associated factors among primary school students in Iran a systematic review and meta-analysis, " Osong public health and research perspectives, 2015; 6(6), pp.346-56.

[26] M. Nazari, M. Saidijam, "Pediculus capitis infestation according to sex and social factors in Hamedan-Iran," Pakistan journal of biological science, 10(19), pp.3473-5, 2007.

[27] A. Saghafipour, J. Nejati, A. Zahraei Ramazani, H. Vatandoost, E. Mozaffari, F. Rezaei, "Prevalence and risk factors associated with head louse (Pediculus humanus capitis) in Central Iran," International Journal of Pediatrics, 5(7), pp.5245-54, 2017.

[28] A. Doroodgar et al., "The prevalence of pediculosis capitis and relevant factors in primary school students of Kashan, Central Iran,” Asian Pacific J. Trop. Dis., vol. 4, no. 6, pp. 500-504, 2014.

[29] S.Ghobakhloo, "Survey the Prevalence of Pediculosis Capitis and its Associated Risk Factors among Girls' Schools Students in Garmsar City, Semnan Province (Iran)," Lett Health Biol Sci 3(1): 20- 26, 2018.

[30] H. Dagne, A.A. Biya, A. Tirfie, W.W. Yallew, B. Dagnew, "Prevalence of pediculosis capitis and associated factors among schoolchildren in Woreta town, northwest Ethiopia,” BMC research notes, 12(1), pp.465, 2019. 